\title{
Analisis Implementasi Pembiayaan Musyarakah Pada Perbankan Syariah (Studi Kasus Pada Bank BRI Syariah KCP Muara Bungo)
}

\author{
Busriadi $^{1}$ \\ Institut Agama Islam (IAI) Yasni Bungo \\ bbusriadi@gmail.com \\ Sandy Kurniadi ${ }^{2}$ \\ Institut Agama Islam (IAI) Yasni Bungo \\ abuzazasdy@gmail.com \\ Hermansyah $^{3}$ \\ Institut Agama Islam (IAI) Yasni Bungo \\ hermansyah@gmail.com
}

\begin{abstract}
Abstrak
Penelitian ini bertujuan implementasi pembiayaan musyarakah pada perbankan syariah studi kasus pada bank BRI Syariah KCP Muara Bungo. Selain itu penelitian ini juga bertujuan untuk mengetahui Untuk mengetahui bagaimana mekanisme pembiayaan musyarakah di BRIS KCP Muara Bungo dan bagaimana upaya BRIS KCP Muara Bungo Untuk Meminimalisir Risiko Pembiayaan Musyarakah, Pendekatan dalam penelitian ini adalah pendekatan penelitian kualitatif deskriptif, Jenis penelitian ini adalah penelitian lapangan (field reseach) yakni pengamatan langsung ke obyek yang diteliti guna mendapatkan data yang relevan. Hasil penelitian menunjukan bahwa pembiayaan musyarakah yang dipraktekkan oleh BRIS KCP Muara Bungo adalah pembiayaan dengan perjanjian usaha antara BRIS dengan nasabah di mana BRIS KCP Muara Bungo mengikut sertakan sebagian dana dalam usaha tersebut. Hasil usaha ini di bagi sesuai dengan kesepakatan bersama dengan mempertimbangkan proporsi modal.
\end{abstract}

Kata Kunci : Pembiayaan, Musyarakah, Bank Syariah

\begin{abstract}
This research aims at implementing musyarakah financing in Islamic banking as a case study at the BRI Syariah KCP Muara Bungo Bank. In addition, this research also aims to find out. To find out how the musyarakah financing mechanism at BRIS KCP Muara Bungo and how BRIS KCP Muara Bungo efforts to Minimize Musyarakah Financing Risks. The approach in this study is a descriptive qualitative research approach. (field reseach), namely direct observation of the object under study in order to obtain relevant data. The results showed that the musyarakah financing that was practiced by BRIS KCP Muara Bungo was financing with a business agreement between BRIS and customers in which BRIS KCP Muara Bungo included a portion of
\end{abstract}

\footnotetext{
${ }^{1}$ Dosen Institut Agama Islam (IAI) Yasni Bungo

${ }^{2}$ Dosen Institut Agama Islam (IAI) Yasni Bungo

${ }^{3}$ Dosen Institut Agama Islam (IAI) Yasni Bungo
} 
Busriadi, Sandy Kurniadi, Hermansyah : Analisis Implementasi Pembiayaan ...

the funds in the business. The results of this business are divided according to mutual agreement by considering the proportion of capital.

Keywords: Financing, Musharaka, Islamic Bank

\section{A. Pendahuluan}

Islam adalah agama yang mengajarkan keselarasan antara dimensi duniawi dan ukhrawi, sehingga untuk mewujudkan keselarasan itu maka ada pengaturan dalam kehidupan manusia dengan sang khaliq dan mengatur hubungan manusia dimasyarakat . Agama Islam dibawa oleh Nabi Muhammad SAW. merupakan agama yang memberikan pedoman kepada umat manusia dalam segala aspek kebutuhan kehidupannya dan menjamin akan mendatangkan kebahagiaan hidup di dunia dan akhirat.4

Islam mewajibkan kaum muslimin untuk berusaha mencari kecukupan nafkah hidup bagi dirinya dan keluarga yang menjadi tanggung jawabnya dengan kekuatan sendiri tidak menggantungkan pertolongan orang lain. ${ }^{5}$ Sebagaimana firman Allah dalam surat Al-Maidah ayat 2

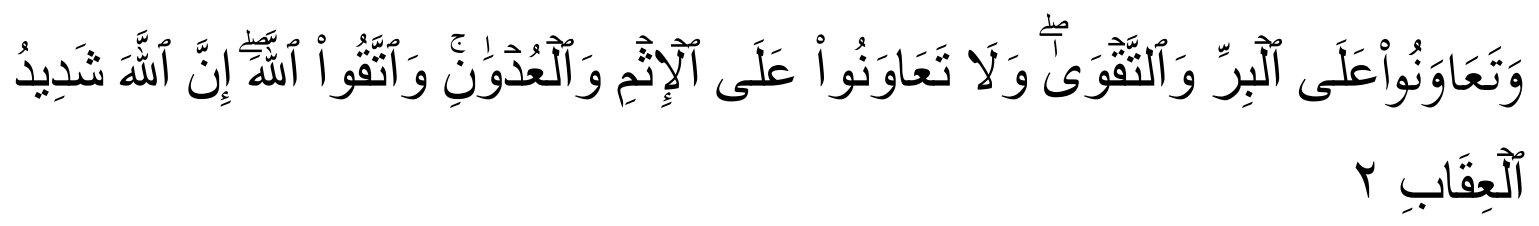

Artinya: Dan tolong-menolonglah kamu dalam (mengerjakan) kebajikan dan takwa, dan jangan tolong-menolong dalam berbuat dosa dan pelanggaran. Dan bertakwalah kamu kepada Allah, sesungguhnya Allah amat berat siksa-Nya. (Q.S Al-Maidah : $2)^{6}$

Namun pada prinsipnya setiap usaha dan pekerjaan ditekankan adanya bentuk kerjasama dan gotong royong. Salah satu bentuk muamalah yang di ajarkan dalam Islam adalah bentuk kerjasama, syirkah atau musyarakah yaitu akad antara dua orang atau lebih dengan menyetorkan modal dengan keuntungan di bagi bersama menurut bagian yang disepakati, musyarakah dapat dilakukan antara seseorang dengan orang lain atau di sebuah lembaga keuangan yaitu bank syariah. Salah satu bisnis yang bersistem Islam dikendalikan oleh sistem halal dan haram, baik dari cara

\footnotetext{
${ }^{4}$ Ahmad Azhar Basyir, Garis Besar Ilmu Ekonomi Islam, (Yogyakarta: UGM BPFE, 1978), h. 1-2.

${ }^{5}$ Ibid., h. 10.

${ }^{6}$ Departemen Agama, Al-Qur'an dan Terjemahannya, (Solo: Pustaka Mantiq, 1997) h. 122.
} 
Busriadi, Sandy Kurniadi, Hermansyah : Analisis Implementasi Pembiayaan ...

perolehan dan pemanfaatan harta dalam lembaga keuangan syariah adalah dengan menggunakan pembiayaan musyarakah. Pembiayaan musyarakah adalah salah satu jenis pembiayaan yang diberikan BRIS KCP Muara Bungo kepada masyarakat.BRIS merupakan salah satu Lembaga Keuangan Syariah yang terdapat di Muara Bungo. Bentuk kerjasama antara pemilik modal dengan pengusaha merupakan pilihan usaha yang lebih efektif untuk meningkatkan etos kerja, karena dalam syirkah tersebut masing-masing mempunyai tanggungjawab untuk menjalankan secara optimal. ${ }^{7}$

Ciri khas yang paling utama adalah adanya prinsip keadilan dan kejujuran. Sesuai dengan prinsip musyarakah di atas, sudah seharusnya bank syariah dalam melakukan pembiayaan musyarakah mengikuti petunjuk teknis pembiayaan musyarakah yang sesuai dengan prinsip- prinsip syariah dan harus menghindari suatu pembiayaan musyarakah yang tidak sesuai dengan prinsip syariah. Dalam pembiayaan berdasarkan akad musyarakah antara bank syariah dan nasabah masing-masing bertindak sebagai mitra usaha dengan bersama-sama menyediakan dana dan atau barang untuk membiayai suatu kegiatan usaha tertentu.

Dari hasil pra riset penulis, penulis mendapatkan praktek pembiayaan musyarakah di BRIS KCP Muara Bungo, pihak BRIS KCP Muara Bungo melakukan akad kerjasama dalam sebuah usaha kepada nasabah.BRIS KCP Muara Bungo mempunyai beberapa produk pembiayaan, salah satunya pembiayaan musyarakah. Pembiayaan musyarakah yang dipraktekkan di BRIS KCP Muara Bungo adalah pihak yang memberikan sebagian modal usaha kepada nasabah untuk menjalankan sebuah usaha, namun nasabah harus mengembalikan modal tersebut kepada BRIS dengan cara angsuran setiap bulan dengan di sertakan besarnya bagi hasil yang telah di tentukan antara pihak BRIS KCP Muara Bungo dan nasabah pada saat dilakukannya perjanjian di awal. Bagi hasil bukan berdasarkan nisbah keuntungan hasil usaha namun berdasarkan besarnya modal awal yang di berikan kepada nasabah.

Jadi dalam pembiayaan musyarakah yang dipraktekkan oleh BRIS KCP Muara Bungo adalah pembiayaan dengan perjanjian usaha antara BRIS dengan nasabah di mana BRIS KCP Muara Bungo mengikut sertakan sebagian dana dalam usaha

\footnotetext{
${ }^{7}$ Ghufron A. Mas'adi, Fiqh Muamalah Konstektual, (Jakarta: PT Raja Grafindo Persada), h. 197-198
} 
Busriadi, Sandy Kurniadi, Hermansyah : Analisis Implementasi Pembiayaan ...

tersebut. Hasil usaha ini di bagi sesuai dengan kesepakatan bersama dengan mempertimbangkan proporsi modal.Jadi permasalahnnya di BRIS KCP Muara Bungo adalah BRIS KCP Muara Bungo hanya mengikut sertakan sebagian modalnya dan tanpa ikut serta dalam kegiatan usaha.

Berdasarkan latar belakang di atas penulis sangat tertarik untuk menganalisis lebih dalam praktek pembiayaan musyarakah dalam lembaga keuangan syariah, apakah sudah sesuai dengan prinsip-prinsip muamalah dalam Islam atau belum. Untuk menganalisis lebih lanjut penulis mengambil tempat penelitian di salah satu lembaga keuangan syariah di BRIS KCP Muara Bungo.

\section{B. Landasan Teori}

Pembiayaan adalah penyediaan uang atautagihan yang dipersamakan dengan itu berdasarkan persetujuan atau kesepakatan antara bank dengan pihak lain yang mewajibkan pihak yang dibiayai untuk mengembalikan uang atau tagihan tersebut setelah jangka waktu tertentu dengan imbalan atau bagi hasil.

Berdasarkan sifat penggunaanya, bank syariah menyalurkan dua jenis pembiayaan, yaitu pembiayaan produktif dan pembiayaan konsumtif. Pembiayaan produktif adalah pembiayaan yang digunakan untuk peningkatan usaha atau bantuan modal bagi peminjamnya, contohnya adalah pembiayaan mudharabah, sedangkan pembiayaan konsumtif adalah pembiayaan yang digunakan untuk memenuhi kebutuhan konsumsi bagi yang meminjamnya.

Jenis pembiayaan berdasarkan prinsip, yaitu pembiayaan bagi hasil, pembiayaan jual-beli, dan pembiayaan sewa (leasing). Pembiayaan bagi hasil adalah pembiayaan yang dilakukan untuk membiayai suatu kegiatan usaha yang berbentuk kerjasama anatara penyedia dana dengan pengelola usaha dimana keuntungan usaha ini dibagi kepada setiap pihak sesuai dengan perjanjian, contohnya adalah pembiayaan mudharabah dan musyarakah. Pembiayaan jual-beli adalah pembiayaan yang dilakukan untuk membiayai pembelian barang atau komoditi berdasarkan prinsip jual-beli, contohnya murabahah,salam dan isthisna. Pembiayaan sewa digunakan untuk usaha perpindahan hak guna atas barang atau jasa, melalui pembayaran upah sewa,dengan atau tanpa diikuti dengan pemindahan kepemilikan atas barang itu sendiri,contohnya ijarah. 
Busriadi, Sandy Kurniadi, Hermansyah : Analisis Implementasi Pembiayaan ...

Musyarakah juga merupakan salah satu jenis usaha patungan dimana terdapat beberapa pihak yang bekerja sama. Pihak yang bekerja sama tersebut menggabungkan sumber daya baik berupa modal usaha dan keterampilan manajerial untuk bersama-sama membentuk sebuah perusahaan (syirkah al inan) sebagai sebuah badan hokum (legal entity) dan mengelolanya. Setiap pihak memiliki bagian secara proposional sesuai dengan kontribusi modal mereka dan mempunyai hak mengawasi (voting rights) perusahaan sesuai dengan proporsinya.

Untuk pembagian keuntungan,setiap pihak menerima pembagian keuntungan sesuai dengan proporsi kontribusi modal mereka,demikian halnya jika usaha tersebut mengalami kerugian, rugi ditanggung sesuai dengan proporsi kontribusi modal. Dengan demikian, dalam musyarakah bank bersama nasabahnya dapat mengumpulkan modal mereka untuk menjalankan suatu usaha bersama.

\section{Pengertian Pembiayaan Musyarakah}

Syirkah merupakan salah satu institusi bisnis tertua yang hingga sekarang masih eksis dan dipraktikkan oleh masyarakat muslim. Secara etimologis, syirkah berarti al- ikhtilath (penggabungan).Menurut ulama' Hanafiah, syirkah secara istilah adalah penggabungan harta untuk dijadikan modal usaha dan hasilnya yang berupa keuntungan atau kerugian dibagi bersama.

Secara terminologis, menurut Kompilasi Hukum Ekonomi Syariah, syirkah (musyarakah) adalah kerjasama antara dua orang atau lebih dalam hal permodalan, ketrampilan, atau kepercayaan dalam usaha tertentu dengan pembagian keuntungan berdasarkan nisbah yang di sepakati oleh pihak-pihak yang terikat. Menurut Fatwa Dewan Syariah Nasional Nomor 08/DSN-MUI/IV/2000 tentang pembiayaan musyarakah, musyarakah adalah pembiayaan berdasarkan akad kerja sama antara dua pihak memberikan kontribusi dana dengan ketentuan bahwa keuntungan dan resiko akan di tanggung bersama sesuai dengan kesepakatan.

Definisi syirkah menurut istilah terdapat perbedaan pendapat dikalangan ulama'.

a. Menurut Hanafiah

Syirkah adalah suatu ungkapan tentang akad (perjanjian) antara dua orang yang berserikat didalam modal dan keuntungan.

b. Menurut Malikiyah 
Busriadi, Sandy Kurniadi, Hermansyah : Analisis Implementasi Pembiayaan ...

Syirkah adalah persetujuan untuk melakukan hak bagi keduanya besertadiri mereka, yakni setiap orang yang berserikat memberikan persetujuan kepada teman serikatnya untuk melakukan hak terhadap harta keduanya disamping masih tetapnya hak bagi masing- masing peserta.

c. Menurut Syafi'iyah

Syirkah menurut syara" adalah suatu ungkapan tentang tetapnya hak atas suatu barang bagi dua orang atau lebih secara bersama-sama.

d. Menurut Hanabilah

Syirkah adalah berkumpul atau bersama-sama dalam kepemilikan atas hak atau tasrruf.

Beberapa aplikasi pembiayaan musyarakah bagi perbankan syariah.

a. Musyarakah permanen, di mana pihak bank merupakan partner usaha tetap dalam suatu proyek atau usaha. Model ini jarang di praktekkan, namun investasi modal permanen ini merupakan alternatif menarik bagi investasi suratsurat berharga atau saham.Dalam musyarakah ini, bank di tuntut untuk terlibat langsung dalam usaha yang menguntungkan selama masing-masing partner musyarakah menginginkannya.

b. Musyarakah digunakan untuk skim pembiayaan modal kerja. Bank merupakan partner pada tahap awal dari sebuah usaha atau proses produksi. Dalam skim ini, pihak bank akan menyediakan dana untuk membeli asset atau alat-alat produksi, begitu juga dengan partner musyarakah lainnya.

c. Musyarakah digunakan untuk pembiayaan jangka pendek. Musyarakah ini bisa diaplikasikan dalam bentuk pembiayaan perdagangan, seperti ekspor, impor, penyediaan bahan mentah atau keperluan-keperluan khusus nasabah lainnya.

2. Landasan Pembiayaan Musyarakah

a. Al-Qur'an

Firman Allah QS. Annisa: 12.

Artinya : Tetapi jika saudara-saudara seibu itu lebih dari seorang, maka mereka bersekutu dalam yang sepertiga itu, sesudah dipenuhi wasiat yang dibuat olehnya atau sesudah dibayar hutangnya dengan tidak memberi mudharat (kepada 
Busriadi, Sandy Kurniadi, Hermansyah : Analisis Implementasi Pembiayaan ...

ahli waris). (Allah menetapkan yang demikian itu sebagai) syari'at yang benar-benar dari Allah, dan Allah Maha Mengetahui lagi Maha Penyantun (Q.S An-nisa":12)

Firman Allah Q.S. Shad: 24

Artinya : Daud berkata: "Sesungguhnya dia telah berbuat zalim kepadamu dengan meminta kambingmu itu untuk ditambahkan kepada kambingnya. Dan sesungguhnya kebanyakan dari orang-orang yang berserikat itu sebahagian mereka berbuat zalim kepada sebahagian yang lain, kecuali orang-orang yang beriman dan mengerjakan amal yang saleh; dan amat sedikitlah mereka ini". Dan Daud mengetahui bahwa Kami mengujinya; maka ia meminta ampun kepada Tuhannya lalu menyungkur sujud dan bertaubat (Q.S. Shad: 24)

b. Al-hadits

"Dari Abu Hurairah, Rasulullah saw bersabda, "Sesungguhnya Allah Azza wa Jalla berfirman,"Aku pihak ketiga dari dua orang yang berserikat selama salah satunya tidakmengkhianati lainnya, apabila berkhiyanat kepada lainnya, maka saya akan keluar dari antara keduanya." (HR Abu Dawud)

Hadits Qudsi tersebut menunujukkan kecintaan Allah kepada hambahambaNya yang melakukan perkongsian selama saling menjunjung tinggi amanat kebersamaan dan menjauhi pengkhianatan. Jika salah seorang yang bersekutu menghiyanati temannya, Allah SWT akan menghilangkan pertolongan dan keberkahan tersebut.

c. Ijma'

Berdasarkan Fatwa Dewan Syariah Nasional No:08/DSN- MUI/IV/2000. Ibnu Qudamah dalam kitabnya, al-Mughni, telah berkata,"Kaum muslimin telah berkosensus terhadap legitimasi musyarakah secara global walaupun terdapat perbedaan pendapat dalam beberapa elemen darinya."

3. Rukun dan Syarat Pembiayaan Musyarakah

a. Rukun pembiayaan musyarakah 
Busriadi, Sandy Kurniadi, Hermansyah : Analisis Implementasi Pembiayaan ...

Ucapan (Sighah) penawaran dan penerimaan (ijab dan qabul). Ucapan ijab dan qabul harus dinyatakan oleh para pihak untuk menunjukkan kehendak mereka dalam mengadakan kontrak (akad), hal-hal yang harus diperhatikan adalah:

a) Penawaran dan penerimaan harus secara eksplisit menunjukkan tujuan kontrak (akad).

b) Penerimaan dari penawaran dilakukan pada saat kontrak.

c) Akad dituangkan secara tertulis.

b. Pihak yang berkontrak.

Pihak-pihak yang berkontrak harus cakap hukum, dan memperhatikan hal-hal berikut:

1) Kompeten dalam memberikan atau diberikan kekuasaan perwakilan.

2) Setiap mitra harus meyediakan dana dan pekerjaan, dan setiap mitra melaksanakan kerja sebagai wakil.

3) Setiap mitra memiliki hak untuk mengatur asset musyarakah dalam proses bisnis normal.

4) Setiap mitra memberi wewenang kepada mitra yang lain untuk mengelola asset dan masing- masing dianggap telah diberi wewenang untuk melakukan aktivitas musyarakah dengan memperhatikan kepentingan mitranya.

5) Seorang mitra tidak diizinkan untuk mencairkan atau menginvestasikan dana untuk kepentingannya sendiri.

c. Objek kesepakatan berupa modal, kerja, keuntungan dan kerugian.

\section{1) Modal}

a) Modal yang diberikan harus uang tunai, emas, perak atau yang nilainya sama.

b) Para pihak tidak boleh meminjam, meminjamkan, menyumbangkan atau menghadiahkan modal musyarakah kepada pihak lain, kecuali atas dasar kesepakatan.

c) Pada prinsipnya, dalam pembiayaan musyarakah tidak ada jaminan, namun untuk menhindari terjadinya pengyimpangan, LKS dapat miminta jaminan.

2) Kerja 
Busriadi, Sandy Kurniadi, Hermansyah : Analisis Implementasi Pembiayaan ...

a) Partisipasi para mitra dalam pekerjaan merupakan dasar pelaksanaan musyarakah, akan tetapi, kesamaan porsi kerja bukanlah merupakan syarat.

b) Setiap mitra melaksanakan kerja dalam musyarakah atas nama pribadi dan wakil dari mitranya.

3) Keuntungan

a) Setiap keuntungan mitra harus dibagikan secara proporsional atas dasar seluruh keuntungan dan tidak ada jumlah yang ditentukan di awal yang ditetapkan bagi seorang mitra.

b) Sistem pembagian keuntungan harus tertuang dengan jelas dalam akad.

4) Kerugian

Kerugian harus dibagi diantara para mitra secara proporsional menurut saham masing-masing dalam modal.

4. Jenis-jenis Pembiayaan Musyarakah

a. Musyarakah Pemilikan, tercipta karena warisan, wasiat, atau kondisi lainnya yang mengakibatkan pemilikan satu aset oleh dua orang atau lebih. Dalam musyarakah ini, kepemilikan dua orang atau lebih berbagi dalam sebuah asset nyata dan berbagi pula dari keuntungan yang dihasilkan asset tersebut. Syirkah dalam kategori ini terbagi menjadi:

1) Syirkah Ikhtiyari (perserikatan di landasi pilihan orang yang berserikat), yaitu perserikatan yang muncul akibat keinginan dua orang atau lebih untuk mengikatkan diri dalam suatu kepemilikan.Seperti dua orang bersepakat membeli suatu barang, atau mereka menerima harta hibah, wasiat dan lain-lain.

2) Syirkah Jabr, yaitu sesuatu yang ditetapkan menjadi milik dua orang atau lebih tanpa kehendak mereka, seperti harta warisan yang mereka terima dari orang yang wafat. Harta syirkah dari seseorang yang meninggal dunia secara otomatis menjadi milik bersama para ahli warisnya.

b. Musyarakah Akad, tercipta dengan cara kesepakatan di mana dua orang atau lebih setuju bahwa tiap orang dari mereka memberikan modal musyarakah, mereka sepakat berbagi keuntungan dan kerugian. Musyarakah Akad terbagi menjadi: 
Busriadi, Sandy Kurniadi, Hermansyah : Analisis Implementasi Pembiayaan ...

\section{1) Syirkah al-'inan}

Syirkah al-„,inan adalah kontrak antara dua orang atau lebih. Setiap pihak memberikan suatu porsi dari keseluruhan dana dan berpartisipasi dalam kerja. Kedua pihak berbagi dalam keuntungan dan kerugian sebagai mana yang disepakati di antara mereka. Akan tetapi, porsi masing-nasing pihak baik dalam dana maupun kerja atau bagi hasil tidak harus sama dan identik sesuai dengan kesepakatan mereka. Mayoritas ulama 'membolehkan jenis al-musyarakah ini. Yang menjadi persoalan di dalam syirkah „inan adalah sebagai berikut:

a) Persyaratan kerja fisik

Dalam syirkah 'inan dibolehkan masing-masing mitra untuk menyepakati persyaratan bahwa masing-masing harus ikut kerja atau salah satu saja yang bekerja.

b) Pembagian keuntungan

Keuntungan yang di raih bisa di bagi sama rata atau ada yang lebih tinggi, sedangkan kerugian yang terjadi harus dibagi menurut kadar saham yang di setor oleh masing-masing mitra.

c) Hilangnya modal syirkah

Jika modal syirkah ini hancur sebagian atau seluruhnya sebelum pembelian dan sebelum dicampur, maka syirkah ini menjadi batal.

d) Menjalankan modal syirkah

Masing-masing mitra berhak untuk menjalankan modal perusahaan karena keduanya telah sepakat untuk berkongsi sehingga menimbulkan pengertian sudah ada izin dari masing-masing untuk menjalankan perusahaannya.

2) Syirkah Mufawadhah

Syirkah mufawadhah adalah kontrak kerja sama antara dua orang atau lebih. Setiap pihak memberikan suatu porsi dari keseluruhan dana dan berpartisipasi dalam kerja. Setiap pihak membagi keuntungan dan kerugian secara sama. Dengan demikian, syarat utama dari jenis al-musyarakah ini adalah kesamaan dana yang diberikan,kerja, tanggungjawab, dan beban utang di bagi oleh masingmasing pihak. Adapun syarat Mufawadhah adalah sebagai berikut:

a) Kesamaan modal di antara masing-masing pihak.

b) Kesamaan wewenang dalam penggunaan modal. Tidak sah suatu syirkah yang dilakukan antara anak kecil dan orang dewasa. 
Busriadi, Sandy Kurniadi, Hermansyah : Analisis Implementasi Pembiayaan ...

c) Kesamaan dalam agama yang dianut. Jadi syirkah tidak berlaku antara orang muslim dan orang kafir.

d) Masing-masing pihak harus menjadi penjamin bagi yang lainnya.

Menurut Imam Malik, Syirkah mufawadhah adalah dua orang atau lebih bekerjasama dalam berniaga dengan dua jumlah harta dengan syarat masing-masing mengambil keuntungan berdasarkan modalnya dan masing- masing pihak memberikan hak mereka mengelola untuk yang lain dalam membeli, menjual, dan mempersewakan, baik ketika orang tersebut hadir maupun tidak hadir.

Menurut Abu Hanifah, syirkah Muwafadhah adalah dua orang atau lebih bekerjasama pada suatu uasaha dengan syarat kedua-duanya modalnya sama (modal seorang tidak boleh lebih), mempunyai hak yang sama. Menurut ulama' Hanabilah, syirkah muwafadhah adalah bekerjasama dalam mencari laba harta, masing-masing dari keduanya menyerahkan urusan jual beli dan lain-lain kepada mitranya.Syirkah semacam ini dari golongan Maliki dan Hanafi membolehkannya, sedangkan Syafi'i melarangnya.

\section{3) Syirkah A'mal}

Al-musyarakah ini adalah kontrak kerja sama dua orang seprofesi untuk menerima pekerjaan secara bersama dan berbagi keuntungan dari pekerjaan itu. Misalnya, kerjasama dua orang arsitek untuk menggarap sebuah proyek. Mazhab Hanafi, Maliki dan Hambali yang di kutip Ismail Nawawi membolehkan musyarakah ini, baik kedua orang tersebut satu profesi maupun tidak.

4) Syirkah Wujuh

Syirkah wujuh adalah kontrak antara dua orang atau lebih yang memiliki reputasi dan prestasi baik serta ahli dalam bisnis.Mereka membeli barang secara kredit dari suatu perusahaan dan menjual barang tersebut secara tunai.Mereka berbagi dalam keuntungan dan kerugian berdasarkan jaminan kepada penyuplai yang disediakan oleh tiap mitra.Kemitraan antara dua orang atau lebih dengan modal dari pihak diluar keduanya, keuntungan dibagi setelah dikurangi dengan modal yang diperoleh dari pihak luar tersebut.

5) Syirkah Mudharabah

Syirkah Mudharabah adalah kontrak kerja sama antara pemilik modal dan seorang pekerja untuk mengelola uang dari pemilik modal dalam perdagangan 
Busriadi, Sandy Kurniadi, Hermansyah : Analisis Implementasi Pembiayaan ...

tertentu. Keuntungannya di bagi sesuai kesepakan bersama, sedangkan kerugian yang di derita menjadi tanggungan pemilik modal.

5. Manfaat Pembiayaan Musyarakah

Terdapat banyak manfaat dari pembiayaan secara musyarakah ini, di antaranya sebagai berikut:

1. Bank akan menikmati peningkatan dalam jumlah tertentu pada saat keuntungan usaha nasabah meningkat.

2. Bank tidak berkewajiban membayar dalam jumlah tertentu kepada nasabah pendanaan secara tetap, tetapi disesuaikan dengan pendapatan/hasil usaha bank, sehingga bank tidak akan pernah mengalami negative spread.

3. Pengembalian pokok pembiayaan sesuai dengan cash flow/arus kas usaha nasabah, sehingga tidak memberatkan nasabah.

4. Bank akan lebih selektif dan hati-hati mencari usaha yang benar-benar halal, aman dan menguntungkan. Hal ini karena keuntungan yang riil dan benar-benar terjadi itulah yang akan dibagikan.

5. Prinsip bagi hasil dalam musyarakah ini berbeda dengan prinsip bunga tetap di mana bank akan menagih penerima pembiayaan (nasabah) satu jumlah bunga tetap berapa pun keuntungan yang dihasilkan nasabah, bahkan sekalipun merugi dan terjadi krisis ekonomi.

Menurut Undang-undang Nomor 21 tahun 2008 tentang perbankan syariah yang dimaksud dengan pembiayaan adalah penyediaan dana atau tagihan yang dipersamakan dengan itu berupa:

1. Transaksi bagi hasil dalam bentuk mudarabahdan musyarakah

2. Tansaksi sewa menyewa dalam bentuk ijarah atau sewabeli dalam bentuk ijarah mutahiyah bittamlik;

3. Transaksi jual beli dalam bentuk piutang murabahah, salam, istishna;

4. Transaksi pinjam meminjam dalam bentuk piutang; dan

5. Transaksi sewa menyewa jasa dalam bentuk ijarahuntuk transaksi multi jasa. ${ }^{8}$

${ }^{8}$ Undang-undang Nomor 21 Tahun 2008 Tentang Perbankan Syariah 
Busriadi, Sandy Kurniadi, Hermansyah : Analisis Implementasi Pembiayaan ...

\section{Metode Penelitian}

Jenis penelitian yang digunakan dalam penelitian ini adalah penelitian lapangan (field research). Suatu penelitian di mana peneliti melihat ke lapangan untuk mengadakan pengamatan tentang sesuatu fenomena dalam suatu keadaan alamiah. ${ }^{9}$

Adapun dalam kajian penelitian hukum, penelitian ini termasuk jenis penelitian normatif empiris. Penelitian empiris atau non-doktrinal adalah penelitian berdasarkan tingkah laku atau aksi-aksi dan interaksi manusia yang secara aktual dan potensial akan terpola. Jadi, penelitian normatif empiris pada dasarnya merupakan penggabungan antara pendekatan hukum normatif dengan unsur empiris. Metode penelitian normatif empiris mengenai implementasi ketentuan hukum normatif (undang-undang) dalam aksinya setiap peristiwa hukum tertentu yang terjadi dalam suatu masyarakat. ${ }^{10}$

Dalam penelitian ini yang sebagai ketentuan hukum normatif adalah ketentuan hukum Islam (fiqh) dan fatwa DSN, sedangkan obyek penelitian ini adalah praktek pembiayaan musyarakah di BRIS KCP Muara Bungo. Penelitian ini adalah penelitian lapangan yang bersifat deskriptif.Penelitian deskriptif adalah penelitian yang yang dimaksudkan untuk mengumpulkan informasi mengenai status suatu gejala yang ada.Metode penelitian kualitatif adalah penelitian yang pemecahan masalahnya dengan menggunakan data empiris. Baik pada penelitian kuantitatif maupun kualitatif desainnya sama, yang membedakan adalah kemauan dan kepentingan penelitian itu sendiri.Sumber data adalah tempat atau orang yang diperoleh. Untuk mencapai kebenaran ilmiah, jenis dan sumber data yang digunakan dalam penelitian ini meliputi:

\section{a. Data Primer}

Data primer adalah sumber yang langsung memberikan data kepada pengumpul data.Sumber data primer dalam penelitian ini adalah data-data yang bersumber dari informan, adapun informan yang telah memberikan data yang berhubungan dengan praktek pembiayaan musyarakah kepada peneliti adalah Ahmad Syarif (PimCapem).Sumber data tersebut memiliki hubungan dengan masalah pokok penelitian sebagai bahan informasi yang dicari.yang terlibat meliputi karyawan BRIS KCP Muara Bungo Adalah Ahmad Syarif selaku analisis pembiayaan Musyarakah BRIS

\footnotetext{
${ }^{9}$ Lexy J Moleong, Metode Penelitian Kualitatif, (Bandung: PT Remaja Rosdakarya, 2009), h. 26.

${ }^{10}$ Burhan Ashshofa, Metode Penelitian Hukum, (Jakarta : Rineka Cipta, 2013), h. 33-34.
} 
Busriadi, Sandy Kurniadi, Hermansyah : Analisis Implementasi Pembiayaan ...

KCP Muara Bungo. Sedangkan konsep yang terjadi di BRIS KCP Muara Bungo dalam pembiayaan musyarakah adalah nasabah harus mengembalikan modal yang diberikan oleh BRIS KCP Muara Bungo setiap bulan dengan disertakan bagi hasil.Penghitungan bagi hasil menurut besarnya modal.

\section{b. Data Sekunder}

Data sekunder adalah sumber yang tidak langsung memberikan data kepada pengumpul data, misalnya melalui orang lain atau dokumen. Sumber data yang mendukung dan melengkapi sumber data primer dalam penelitian ini yaitu buku, jurnal, surat-surat atau laporan yang telah tersedia, meliputi dokumen- dokumen BRIS KCP Muara Bungo.

\section{Hasil dan Pembahasan}

\section{Mekanisme Pembiayaan Musyarakah di BRIS KCP Muara Bungo.}

Pembiayaan modal kerja di BRI Syariah KCP Muara Bungo adalah sebuah pembiayaan untuk memenuhi kebutuhan modal kerja atau modal investasi yang digunakan untuk pemenuhan barang dagangan,penambahan bahan baku produksi, dan pembelian alatalat kerja.

Pembiayaan modal kerja yang ditetapkan oleh BRI Syariah memiliki 2 akad yaitu akad murabahah dan akad musyarakah. Akan tetapi terdapat perbedaan pada penggunaan akad, jika menggunakan akad mudharabah maka berbentuk modal kerja linkage yaitu pembiayaan yang ditujukan untuk kebutuhan modal kerja yang bersifat kerjasama dengan lembaga keuangan yang berbadan hukum seperti Koperasi Multifinansial. Sedangkan jika menggunakan akad musyarakah maka termasuk pembiayaan modal kerja ritel, yaitu pembiayaan yang ditujukan untuk usaha produktif.

Dalam prakteknya BRI Syariah KCP Muara Bungo lebih sering menggunakan akad Musyarakah sebagai akad pembiayaan modal kerja, karena menurut pihak BRI Syariah KCP Muara Bungo. sebagian besar nasabah yang bernegosiasi dengan Customer Service dan Account Officer mengarahkan pada pembiayaan dengan akad musyarakah.

Berikut mekanisme pembiayaan modal kerja dengan akad musyarakah di BRI Syariah KCP Muara Bungo:

a. Nasabah melakukan permohonan pembiayaan dengan datang langsung ke BRI Syariah KC

Semarang dan menyerahkan dokumen persyaratan pada pihak bank.

1) Identitas Pribadi berupa : 
Busriadi, Sandy Kurniadi, Hermansyah : Analisis Implementasi Pembiayaan ...
a) Fotocopy KTP
b) Fotocopy KK
c) Fotocopy NPWP
d) Fotocopy Akta Nikah
e) Foto copy SIUP (surat izin usaha perdagangan)
f) Foto copy TDP (Tanda daftar perusahaan)

2) Financial Nasabah
a) Fotocopy Laporan keuangan Nasabah
b) Fotocopy Mutasi Rekening hasil penjualan dan pendapatan Nasabah

3) Jaminan
a) Fotocopy Jaminan yang akan dijadikan Agunan pembiayaan
b) Foto copy IMB
c) Foto copy PBB/ Pajak

a. Selanjutnya AO (Acounting Officer) melakukan Analisis pada Nasabah sampai disetujui oleh komite pembiayaan yaitu Manager Marketing, Pimpinan Cabanng Pembantu, Pipminan Cabang, atau Kantor Pusat,

b. Dilakukan BI Cheking untuk mengetahui history pinjaman nasabah sebelum dilakukan akad, dan sebagai pertimbangan apakah nasabah tersebut lancar atau tidak dalam memenuhi kewajiban angsurannya.

c. Untuk mengetahui berapa nilai market dengan melihat kondisi jaminan pada nasabah dilakukan penilaian oleh pihak appraisal, nilai market berfungsi untuk tolak ukur besar kecilnya plafond yang bisa nasabah pinjam.

d. Selanjutnya dilakukan akad pembiayaan musyarakah dengan notaris dan dihadiri oleh pihak marketing, Pimpinan Cabang Pembantu atau Pimpinan Cabang sebagai pihak bank.

e. Lalu dilakukan review prabooking oleh pihak ADP sebelum dilakukan pencairan,yang bertujuan agar mengetahui sudah terpenuhi semua atau belum persyaratan yang telah ditentukan oleh komite, setelah semua terpenuhi dilakukan input data pencairan.

f. Setelah dana pembiayaan cair, AO wajib melakukan monitoring nasabah sampai nasabah tersebut melunasi kreditnya. ${ }^{11}$

Untuk mekanisme bagi hasil dihitung berdasarkan nisbah bagi hasil pada BRI Syariah yang sudah disepakati kedua belah. Praktek musyarakah dalam BRISyariah menjadi hal yang

\footnotetext{
${ }^{11}$ Ahmad Syarif, Pimpinan Cabang BRIS KCP Muara Bungo, Hasil Wawancara, Tanggal 08 Desember 2020
} 
Busriadi, Sandy Kurniadi, Hermansyah : Analisis Implementasi Pembiayaan ...

sangat penting dalam penulisan skripsi ini, karena dalam karya ilmiah ini penulis akan mengkaji lebih lanjut tentang mekanisme musyarakah di BRISyariah. Musyarakah sebagai kerjasama kemitraan antara Bank dan nasabah, yang mengedepankan prinsip kejujuran dan kemitraan adalah salah satu usaha mewujudkan keadilan muamalah melalui konsep bagi hasil dan kemitraan.

BRIS KCP Muara Bungosebagai lembaga keuangan syariah pastinya mempunyai tujuan yang umumnya sama dalam menawarkan produk pembiayaan dengan akad musyarakah dan akad lain.Risiko terbesar yang dihadapi oleh perbankan pada pembiayaan bisnis pembiayaan adalah RISIKO KREDIT yaitu terjadinya Kredit Bermasalah/Kredit Macet. Kredit dikatakan bermasalah jika terjadi pelanggaran perjanjian kredit yang biasanya diikuti dengan kemacetan kredit. Hal ini akibat kegagalan debitur dan/atau pihak lain dalam memenuhi kewajiban kepada Bank yang ditandai dengan gejala seperti :

a. Menurunnya aktifitas rekening nasabah.

b. Adanya tunggakan atas pembayaran kewajibannya yang berulang setiap bulannya.

c. Adanya peningkatan secara signifikan pemakaian plafon yang diberikan

d. Sering melakukan penarikan Cek/Bilyet Giro dengan saldo tidak cukup

e. Waktu hutang kepada konsumen menjadi lebih panjang

f. Waktu piutang kepada supplie rmenjadi lebih pendek

g. Nasabah susah dihubungi

h. Banyaknya usaha sejenis yang mengalami penurunan penjualan.

Gejala-gejala tersebut dapat terjadi dikarenakan beberapa penyebab yang muncul baik dari sisi internal maupun eksternal suatu bank

a. Faktor Eksternal Bank :

1) Kondisi manajemen debitur

2) Kegagalan usaha debitur

3) Side Streaming olehdebitur

4) Itikad kurang baik debitur

5) Kondisi ekonomi makro (Depresiasi, Devaluasi dan inflasi)

6) Kebijakan Pemerintah (Deregulasi dll).

b. FaktorInternal Bank :

1) Pertumbuhan kredit yang berlebihan

2) Penyimpangan Ketentuan/Prosedur

3) Lemahnya sistem monitoring dan pengawasan dari internal Bank 
Busriadi, Sandy Kurniadi, Hermansyah : Analisis Implementasi Pembiayaan ...

Guna mencegah kredit bermasalah maka ada beberapa hal yang dapat dilakukan oleh pihak BRI Syariah yaitu:

a. Menjaga \& memelihara dokumen kredit.

b. Memonitoring kredit \& mutasi rekening debitur, termasuk mengawasi cerukan (Over Draft).

c. Memonitoring setiap aktivitas usaha debitur.

d. Mewaspadai faktor-faktor Eksternal dan Internal debitur.

e. Memberikan perhatian khusus kepada perusahaan/ debitur yang mengalami pertumbuhan luar biasa.

Untuk meminimalisir terjadinya risiko kredit tersebut, maka diperlukan pemahaman terhadap dasar-dasar prinsip analisa pembiayaan, antara lain menggunakan prinsip "5 $\mathrm{C}$ Principles of Credit” : Character, Capacity, Capital, Collateral \& Condition of Economics.

a. Character

Untuk memperoleh gambaran tentang karakter calon Debitur dalam kemauan dan kemampuan, kejujuran, integritas, stabilitas serta motivasi untuk membayar angsuran yang dapat ditempuh upaya-upaya sebagai berikut:

1) Meneliti riwayat hidup dari calon Debitur.

2) Meneliti reputasi di tempat usaha calon Debitur.

3) Meminta informasi dari bank ke bank yang pernah memberikan fasilitas pembiayaan (Bank Information).

4) Mencari informasi kehidupan calon nasabah dari lingkungan tempat tinggal (trade checking).

b. Capacity (capability)

Untuk melihat sejauh mana kemampuan calon Debitur dalam membayar kewajibannya yang dihubungkan dengan kemampuannya mengelola bisnis serta kemampuannya mencari laba. Semakin banyak pendapatannya /pemasukannya maka semakin besar kemampuannya dalam mengembalikan pinjamannya. Kita bisa menilai capasity dari calon Debitur dengan cara:

1) Menilai kekayaan nasabah, dengan cara melihat seberapa besar aset yang dimiliki oleh calon Debitur.

2) Melihat laporan keungan dari usaha yang dilakukan calon Debitur (Past Financial Performance).

3) Melihat perkembangan usaha yang dilakukan oleh calon Debitur.

c. Capital 
Busriadi, Sandy Kurniadi, Hermansyah : Analisis Implementasi Pembiayaan ...

Capital/ modal yang dimaksud di sini adalah ketersediaan modal awal nasabah sebelum mengajukan pembiayaan. Poin capital ini tidak terlalu dipertimbangkan oleh BRI Syariah, Dibandingkan dengan karakter, kapasitas (kemampuan membayar anggota), dan agunan/jaminan. Akan tetapi poin ini masih dinilai juga demi keamanan dan kehati-hatian BRI Syariah dalam menyalurkan pembiayaan. Dan biasanya BRI Syariah tidak akan memberikan pembiayaan untuk modal usaha 100\%. Dilihat dari modal yang di gelontorkan nasabah atau mitra yang digunakan untuk usaha maka semakin banyak modal yang dipakai semakin bersungguh-sungguh pula nasabah dalam menjalani usahanya.

c. Colleteral

Menilai dan menganalisis agunan yang agunkan ke BRI Syariah. Nilai dari jaminan diharuskan jumlahnya tinggi dibanding dengan pinjamanya, pinjaman diharuskan sebesar 75\% dari nilai jaminan yang diagunkan. Menilai juga keabsahan atau keaslian dari jaminan, yang akan bisa dipergunakan secepat mungkin apabila terjadi suatu masalah.

d. Condition

Melihat kondisi lingkungan saat pemberian pembiayaan baik kondisi ekonomi yang terjadi maupun politik. Sehingga dibutuhkan kondisi yang stabil dalam pengucuran dana pembiayaan. Dan apabila dalam kondisi yang tidak setabil pembiayaan tetap diberikan maka perlu dilihat prospek usaha tersebut dimasa yang akan datang.

\section{Meminimalisir Risiko Pembiayaan Musyarakah.}

Dari uraian sebelumnya dapat diketahui bahwa produk pembiayaan musyarakah di Muara Bungo memiliki. permasalahan utama yaitu risiko kredit atau yang biasa disebut dengan kredit macet/bermasalah Kredit bermasalah dapat disebabkan oleh faktor dari internal Bank atau dari eksternal (Nasabah dan kondisi ekonomi).

Dari berbagai strategi yang dilakukan pihak BRI Syariah untuk meminimalisir risiko kredit dapat di klasifikasikan menjadi 2 yaitu strategi yang dilakukan sebelum pencairan dana pembiayaan dan sesudah pencairan dana.

a. Sebelum Pencairan Dana Pembiayaan

Strategi sebelum pencairan dana pembiayaan dilakukan dengan cara verifikasi Nasabah dari mulai permohonan pembiayaan, dokumen persyaratan, jaminan sampai dengan peninjauan langsung lingkungan tempat usaha. Mekanisme tersebut dilakukan dengan menganut prinsip 5C (Character, Capacity, Capital, Collateral \& Condition of Economics) dan 7P (People, Purpose, Payment, Protection, Prospective, Party \& Profitability).

b. Setelah Pencairan Dana Pembiayaan 
Busriadi, Sandy Kurniadi, Hermansyah : Analisis Implementasi Pembiayaan ...

Setelah persetujuan pembiayaan dari BRI Syariah juga melakukan langkah-langkah dalam meminimalisir risiko pembiayaan, yaitu melakukan monitoring terhadap nasabah sampai pelunasan kredit.

Dari segi klasifikasi nasabah, BRI Syariah membagi kategori nasabah menjadi 4 tingkatan

a. Kategori I : Nasabah/Debitur mempunyai kemauan dan kemampuan yang tinggi. Sehingga tindak lanjut yang dilakukan pihak BRI Syariah yaitu penagihan dan monitoring.

b. Kategori II : Nasabah/Debitur mempunyai kemauan namun kemampuan terbatas. Sehingga tindak lanjut yang dilakukan pihak BRI Syariah yaitu restrukturisasi.

c. Kategori III: Nasabah/Debitur mempunyai kemauan yang rendah tetapi kemampuan tinggi. Sehingga tindak lanjut yang dilakukan pihak BRI Syariah yaitu pembinaan.

d. Kategori IV : Nasabah/Debitur mempunyai kemauan dan kemampuan yang rendah. Sehingga tindak lanjut yang dilakukan pihak BRI Syariah yaitu pembinaan dan usulan ulang pada unit pembiayaan.

Dalam prakteknya penerapan strategi diatas untuk meminimalisir risiko pembiayaan musyarakah oleh BRI Syariah KCP Muara Bungo dapat dianggap berhasil, dengan indikasi kelancaran Nasabah/Debitur dalam membayar angsuran dan ketepatan waktu pelunasan kreditnya sesuai dengan kesepakatan awal.

Dari pengamatan yang dilakukan penulis strategi BRI Syariah mempunyai beberapa kelebihan dan kekurangan yang dapat dianalisis menggunakan pendekatan analisis SWOT :

a. Strenght

BRI Syariah menerapkan prinsip 5C dan 7P dengan baik dan mempunyai kekuatan manajerial serta manajemen risiko yang baik sebagai lembaga keuangan Syariah yang menyediakan produk pembiayaan modal kerja musyarakah.

b. Weakness

BRI Syariah masih belum populer di kalangan masyarakat secara luas, karena masih di sekitar kawasan perkotaan saja maka jangkauannya kurang menyeluruh. Padahal sendi ekonomi tidak hanya di perkotaan.

c. Opportunity

Kebutuhan usaha di era modern sekarang ini terutama di kawasan perkotaan membutuhkan modal yang cukup besar.

d. Threat

Nasabah/Debitur yang bermasalah. Dan persaingan antar lembaga keuangan.

\section{E. Kesimpulan}


Busriadi, Sandy Kurniadi, Hermansyah : Analisis Implementasi Pembiayaan ...

1. Berdasarkan hasil peneltian mekanisme pembiayaan modal kerja dengan akad musyarakah di BRI Syariah KCP Muara Bungo adalah sebagai berikut :

a. Nasabah melakukan permohonan pembiayaan dengan datang langsung ke BRI Syariah KC Semarang dan menyerahkan dokumen persyaratan pada pihak bank.

b. Selanjutnya AO (Acounting Officer) melakukan Analisis pada Nasabah sampai disetujui oleh komite pembiayaan yaitu Manager Marketing, Pimpinan Cabanng Pembantu, Pipminan Cabang, atau Kantor Pusat

c. Dilakukan BI Cheking untuk mengetahui history pinjaman nasabah sebelum dilakukan akad, dan sebagai pertimbangan apakah nasabah tersebut lancar atau tidak dalam memenuhi kewajiban angsurannya.

d. Untuk mengetahui berapa nilai market dengan melihat kondisi jaminan pada nasabah dilakukan penilaian oleh pihak appraisal, nilai market berfungsi untuk tolak ukur besar kecilnya plafond yang bisa nasabah pinjam.

e. Selanjutnya dilakukan akad pembiayaan musyarakah dengan notaris dan dihadiri oleh pihak marketing, Pimpinan Cabang Pembantu atau Pimpinan Cabang sebagai pihak bank.

f. Lalu dilakukan review prabooking oleh pihak ADP sebelum dilakukan pencairan,yang bertujuan agar mengetahui sudah terpenuhi semua atau belum persyaratan yang telah ditentukan oleh komite, setelah semua terpenuhi dilakukan input data pencairan.

g. Setelah dana pembiayaan cair, AO wajib melakukan monitoring nasabah sampai nasabah tersebut melunasi kreditnya.

2. Musyarakah sebagai kerjasama kemitraan antara Bank dan nasabah, yang mengedepankan prinsip kejujuran dan kemitraan adalah salah satu usaha mewujudkan keadilan muamalah melalui konsep bagi hasil dan kemitraan.BRIS KCP Muara Bungo sebagai lembaga keuangan syariah pastinya mempunyai tujuan yang umumnya sama dalam menawarkan produk pembiayaan dengan akad musyarakah dan akad lain.Karena Nasabah memerlukan tambahan modal maka mengajukan pembiayaan ke Bank Syariah dan kedua pihak sepakat melakukan perjanjian kontrak pembiayaan modal kerja dengan akad Musyarakah. Selanjutnya Bank Syariah mencairkan dana pembiayaan modal kerja sesuai yang diajukan oleh nasabah.

3. Untuk meminimalisir terjadinya risiko kredit tersebut, maka diperlukan pemahaman terhadap dasar-dasar prinsip analisa pembiayaan, antara lain menggunakan prinsip "5 C Principles of Credit" : Character, Capacity, Capital, Collateral \& Condition of Economics. 
Busriadi, Sandy Kurniadi, Hermansyah : Analisis Implementasi Pembiayaan ...

Strategi yang dilakukan pihak BRI Syariah untuk meminimalisir risiko kredit dapat di klasifikasikan menjadi 2 yaitu strategi yang dilakukan sebelum pencairan dana pembiayaan dan sesudah pencairan dana.

a. Sebelum Pencairan Dana Pembiayaan

Strategi sebelum pencairan dana pembiayaan dilakukan dengan cara verifikasi Nasabah dari mulai permohonan pembiayaan, dokumen persyaratan, jaminan sampai dengan peninjauan langsung lingkungan tempat usaha.

b. Setelah Pencairan Dana Pembiayaan

Setelah persetujuan pembiayaan dari BRI Syariah juga melakukan langkah-langkah dalam meminimalisir risiko pembiayaan, yaitu melakukan monitoring terhadap nasabah sampai pelunasan kredit.

\section{Daftar Pustaka}

Ahmad Azhar Basyir, Garis Besar Ilmu Ekonomi Islam, Yogyakarta: UGM BPFE, 1978.

Departemen Agama, Al-Qur'an dan Terjemahannya, Solo: Pustaka Mantiq, 1997.

Ghufron A. Mas'adi, Fiqh Muamalah Konstektual, Jakarta: PT Raja Grafindo Persada.

Undang-undang Nomor 21 Tahun 2008 Tentang Perbankan Syariah

Lexy J Moleong, Metode Penelitian Kualitatif, Bandung: PT Remaja Rosdakarya, 2009.

Burhan Ashshofa, Metode Penelitian Hukum, Jakarta : Rineka Cipta, 2013.

Ahmad Syarif, Pimpinan Cabang BRIS KCP Muara Bungo, Hasil Wawancara, Tanggal 08

Desember 2020.

Paradina, N. E. (2021). Pengaruh Kompetensi, Independensi, Etika Auditor, Dan Integritas Terhadap Kualitas Audit (Studi Kasus pada BPKP Provinsi Jambi). ISTIKHLAF: Jurnal Ekonomi, Perbankan Dan Manajemen Syariah, 3(1), 90-104. 